\title{
Autoantibodies and Malaria: Where We Stand? Insights Into Pathogenesis and Protection
}

\author{
Luiza Carvalho Mourão, Gustavo Pereira Cardoso-Oliveira and Érika Martins Braga* \\ Departamento de Parasitologia, Instituto de Ciências Biológicas, Universidade Federal de Minas Gerais, Belo Horizonte, Brazil
}

OPEN ACCESS

Edited by:

Patricia Sampaio Tavares Veras, Gonçalo Moniz Institute (IGM), Brazil

Reviewed by:

Kai Yang,

Indiana University School of Medicine-Lafayette, United States

Surya Prakash Pandey, University of Pittsburgh, United States Ann M. Moormann, University of Massachusetts Medical School, United States

*Correspondence: Érika Martins Braga embraga@icb.ufmg.br

Specialty section:

This article was submitted to Microbes and Innate Immunity, a section of the journal Frontiers in Cellular and Infection Microbiology

Received: 03 January 2020 Accepted: 04 May 2020 Published: 11 June 2020

Citation: Mourão LC, Cardoso-Oliveira GP and Braga ÉM (2020) Autoantibodies and Malaria: Where We Stand? Insights Into Pathogenesis and Protection.

Front. Cell. Infect. Microbiol. 10:262. doi: 10.3389/fcimb.2020.00262
Autoantibodies are frequently reported in patients with malaria, but whether they contribute to protection or to pathology is an issue of debate. A large body of evidence indicates that antibodies against host-self components are associated to malaria clinical outcomes such as cerebral malaria, renal dysfunction and anemia. Nonetheless, self-reactive immunoglobulins induced during an infection can also mediate protection. In light of these controversies, we summarize here the latest findings in our understanding of autoimmune responses in malaria, focusing on Plasmodium falciparum and Plasmodium vivax. We review the main targets of self-antibody responses in malaria as well as the current, but still limited, knowledge of their role in disease pathogenesis or protection.

Keywords: malaria, autoantibodies, anemia, cerebral malaria, renal dysfunction

\section{INTRODUCTION}

Despite substantial progress in control efforts over the past decades, malaria still accounts for significant morbidity and mortality, mainly in underdeveloped countries. In 2018, an estimated 228 million cases of malaria occurred worldwide with 405,000 deaths, largely in Africa (WHO | World Malaria Report, 2019). Five species are known to cause malaria in humans, Plasmodium falciparum, Plasmodium vivax, Plasmodium knowlesi, Plasmodium ovale, and Plasmodium malariae. Since research emphasis has been placed on $P$. falciparum and $P$. vivax, parasites that are responsible for most of malaria cases, here we will focus in these two species.

Symptomatic disease occurs during the erythrocytic phase when the presence of asexual blood-stage parasites triggers a robust innate immune response. This response if properly regulated may clear infection, contributing to the development of a protective immunity. By the other hand, if not counterbalanced by anti-inflammatory responses, the exacerbated activation of the immune system may play a key role in the pathogenesis (reviewed by Antonelli et al., 2019), leading to complications such as cerebral malaria, anemia, acute kidney injury and respiratory distress syndrome (Moxon et al., 2019).

During infection, high levels of antibodies with a broad range of specificities are elicited. Although their functional activity is far from over, it is known that such molecules can have diverse effects. Antibodies are critical for the control of the disease by acting alone or in cooperation with host immune cells (For further details see Teo et al., 2016). But in some cases, antibodies that recognize host's own components may also promote pathology (Ludwig et al., 2017).

The presence of autoantibodies that recognize the host's own molecules has also been extensively reported in patients with malaria (Rosenberg et al., 1973; Berzins et al., 1983; Daniel-Ribeiro et al., 1983; Wozencraft et al., 1990; Jakobsen et al., 1993; Lacerda et al., 2011; Fernandez-Arias et al., 2016; Mourão et al., 2016, 2018; Rivera-Correa et al., 2019a). The mechanisms by which autoimmune responses could be triggered during an infection remains unclear but it is generally 
accepted that they may include: molecular mimicry (Damian, 1964; Greenwood, 1974), bystander activation (Fujinami et al., 2006; Münz et al., 2009), epitope spreading (Vanderlugt and Miller, 2002; Münz et al., 2009), persistent infection and B cells polyclonal activation (Freeman and Parish, 1978; Rosenberg, 1978; Daniel-Ribeiro et al., 1983; Minoprio, 2001).

Molecular mimicry is the sharing of structurally similar antigens between parasite and host components (Damian, 1964). In malaria, molecular mimicry occurs between $P$. falciparum translationally controlled tumor protein (PfTCTP) and human histamine-releasing factor (HRF) (MaCDonald et al., 2001). Another plasmodial protein that share motifs with host's components is $P$. falciparum erythrocyte membrane protein 1 (PfEMP1), which exhibits homology with human vitronectin (Ludin et al., 2011). An in silico analysis comparing P. vivax entire proteome and human $\mathrm{RBC}$ proteome also revealed that 23 P. vivax proteins shared similarity to human RBC proteins such as ankyrin, actin, and spectrin (Mourão et al., 2018). These structural similarities can activate cross-reactive autoreactive lymphocytes, consequently disordering the immune system. So, when $\mathrm{T}$ - or B- cells receptors recognize a parasite epitope that is similar enough to a self-protein, an autoimmune response is elicited, leading to cell or tissue destruction in addition to activation of other branches of the immune system (Fujinami et al., 2006; Münz et al., 2009).

Bystander activation is an antigen-independent phenomenon whereby parasitized cells, either through direct cell contact or paracrine signals, alert or instruct neighboring non-infected cells to produce inflammatory mediators (Holmgren et al., 2017). The inflammatory milieu evoked by the infection promotes the activation and expansion of autoreactive $\mathrm{T}$ or $\mathrm{B}$ cells, which can initiate an autoimmune response that damage host's cells or tissues, leading to the release of self-reactive antigens (Fujinami et al., 2006; Münz et al., 2009). Evidences of bystander activation in malaria came from in vitro studies investigating the pathways driving inflammation in infection. These studies have demonstrated that extracellular vesicles derived from plasma of mice infected with Plasmodium berghei or from P. falciparuminfected erythrocytes were able to activate naïve host cells (Couper et al., 2010; Mantel et al., 2013).

It is widely known that in early immune responses, epitopes of the initial antigens are recognized by the acquired immune system, but during infection, epitopes other than the dominant ones may also become immunogenic and be targets of $\mathrm{T}$ and B cells. This reactivity to newer endogenous epitopes is termed "epitope spreading" and may be induced against other epitopes in the same autoantigen (intramolecular epitope spreading) or against epitopes in other self-antigens (intermolecular epitope spreading) that are released after T- or B-cell-mediated bystander (Münz et al., 2009). Although epitope spreading is more commonly reported in autoimmune diseases, it may also occur in persistent infections, as it has been suggested by Flanagan et al. (2006) in a study conducted with adults naturally exposed to malaria in Kenya. These authors have investigated cellular immunity to the thrombospondin-related adhesive protein of P. falciparum (PfTRAP) and showed that the immunodominant response stimulated in the primary exposure to this protein has progressed to encompass lesser epitopes with repeated and prolonged exposure.

In vitro experiments with $P$. falciparum-infected RBCs revealed that culture supernatant containing parasite-derived products was able to induce polyclonal B-cell activation and non-specific immunoglobulin synthesis, suggesting that B-cell's proliferation and differentiation into antibody-secreting cells triggered by pathogen's molecules can also lead to autoimmune responses (Freeman and Parish, 1978; Minoprio, 2001). One of the molecules that has been incriminated as a potential activator of B-cells in malaria is the cysteine-rich interdomain region 1 (CIDR1) of $P$. falciparum erythrocyte membrane protein 1 (PfEMP-1). Evidence in this line has been provided by a study with B cells from non-immune donors stimulated with a recombinant version of CIDR1. The recombinant protein was able to promote in vitro proliferation, increase in B-cell size, and expression of immunoglobulins and cytokines in those cells (Donati et al., 2004). However, just a small proportion of antibodies secreted by them was specific for parasite antigens; the greater part was non-specific and could react with different host's components, leading to cell and tissue damage.

Self-reactive antibodies recognize different self-antigens such as erythrocyte proteins (Rosenberg et al., 1973; Fontaine et al., 2010; Mourão et al., 2016, 2018; Ventura et al., 2018), brain molecules (Bansal et al., 2009; Gitau et al., 2013), phospholipids (Adebajo et al., 1993; Jakobsen et al., 1993; Facer and Agiostratidou, 1994; Fernandez-Arias et al., 2016; Barber et al., 2019; Rivera-Correa et al., 2019a,b), and nucleic acids (Adu et al., 1982; Adebajo et al., 1993; Rivera-Correa et al., 2019b). Although the literature reporting the detection of autoantibodies in plasmodial infections is vast, the role of such molecules in malaria is still a controversial issue. Some authors have associated such autoimmune responses to pathology while others to protection. In this review, we summarize the latest breakthroughs regarding autoantibody responses in malaria, emphasizing what is new on the pathogenesis front, mainly with respect to cerebral malaria, kidney injury and anemia (Figure 1).

\section{CEREBRAL MALARIA}

Cerebral malaria (CM) is a clinical syndrome of severe falciparum malaria characterized by impaired consciousness assessed by Blantyre Coma Score $\leq 2$ in children (Molyneux et al., 1989) or Glasgow Coma Score $\leq 11$ in adults (Teasdale and Jennett, 1974), with no other cause of encephalitis (Taylor et al., 2004). Although this neurological syndrome only develops in a small percentage of $P$. falciparum-infected patients, it is responsible for more than $90 \%$ of malaria-related deaths. The treatment with anti-malarial drugs decreases mortality due to CM, but nearly $20 \%$ of treated patients still succumb and up to one-third of survivors frequently exhibit long-term neurological sequelae such as cognition and speech disorders, physical disability and cortical blindness (Birbeck et al., 2010).

Although the mechanisms leading to $\mathrm{CM}$ pathogenesis are not yet clearly defined, it is known that both parasite and host factors play a role in the clinical outcome of this syndrome (Idro 


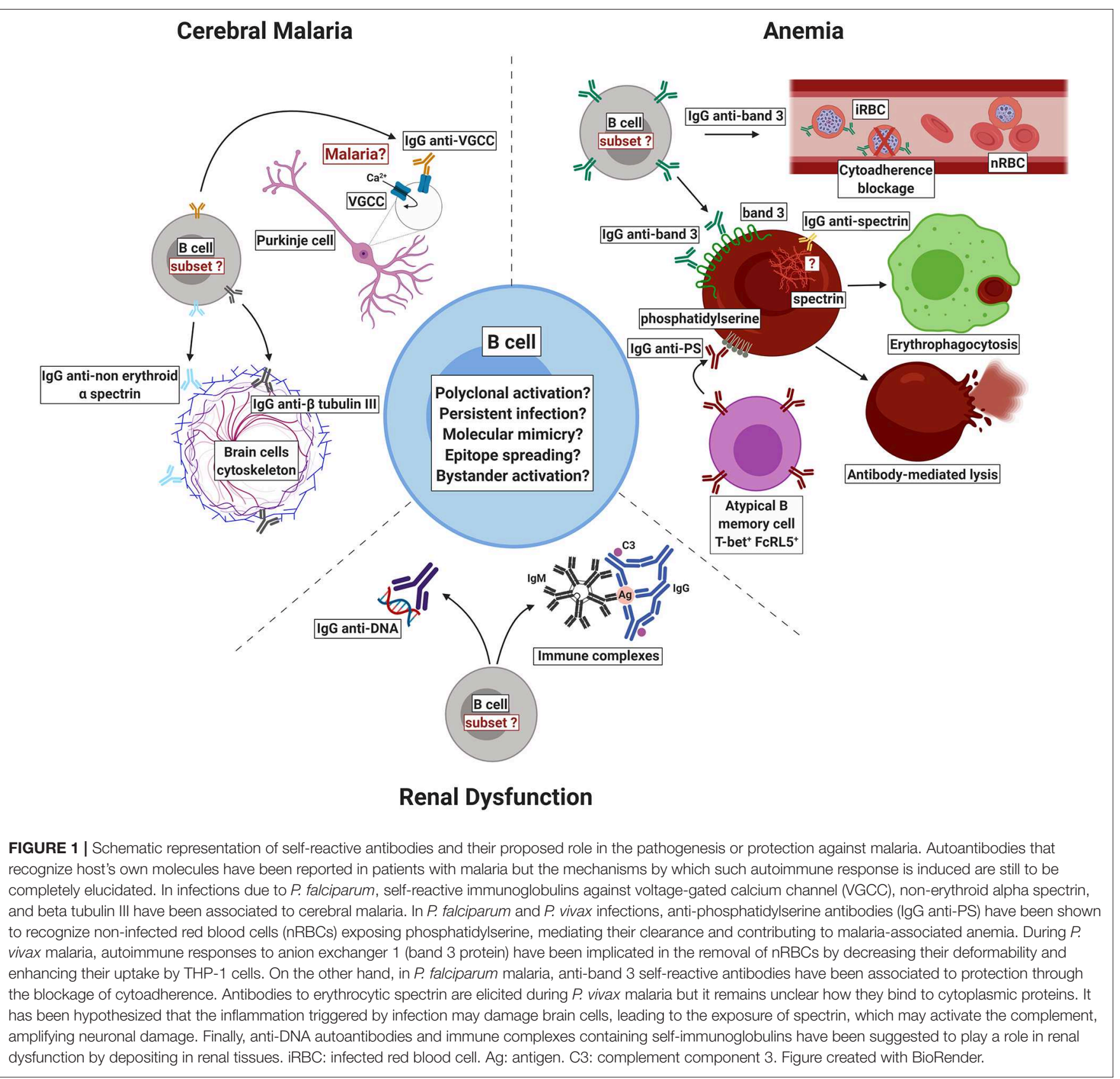

et al., 2010). Among host components, B cells and antibodies are critical for the immune response against malaria. Large amounts of antibodies are produced in response to plasmodial infection, including those that recognize self-components such as host brain antigens (Guiyedi et al., 2007; Bansal et al., 2009; Duarte et al., 2012). However, whether such self-reactive immunoglobulins are a consequence of cerebral malaria or a factor that aggravates the disease is little explored. This could be, in part, due to the difficult in accessing human brain tissues because of the small proportion of $P$. falciparuminfected patients that develop CM. Moreover, the existence of ethical issues limits the study of CM to peripheral blood and post-mortem samples.
Although understudied, some research groups have associated a marked increase in specific anti-brain autoantibodies levels with disease severity in P. falciparum malaria. This is the case of self-reactive antibodies against the voltage-gated calcium channels (VGCCs), whose levels were shown to be higher in Kenyan children with CM than in those with uncomplicated disease or uninfected (Lang et al., 2005). Autoantibodies to VGCCs have been shown to downregulate calcium flow in Purkinje neurons and granule cells through a complementindependent process in autoimmune diseases such as limbic encephalitis and cerebellar ataxia (Pinto et al., 1998; Irani and Lang, 2008), thereby providing insight into the pathogenic role of such self-reactive molecules in malaria. 
Furthermore, it has been reported that serum from Gabonese children with severe $P$. falciparum infection recognize a higher diversity of brain antigens in comparison to non-infected ones. Some of those autoantibodies display reactivity to the non-erythroid alpha spectrin (Guiyedi et al., 2007), a structural protein that is found in the cytoplasm of a variety of brain cells and is responsible for membrane structure and integrity. Since inflammation induced by malaria can damage brain cells exposing non-erythroid alpha spectrin, it is possible that this protein activates the complement system, amplifying the neuronal damage. In primary Sjögren's syndrome, an important autoimmune disease, non-erythroid spectrin undergoes proteolysis by caspase 3 and calpain, producing a fragment that acts as autoantigen (Nath et al., 1996; Haneji et al., 1997).

Other cytoskeletal protein that has also been described as a target of autoimmune responses in CM and which is considered as a disease-specific marker is beta tubulin III (TBB3) (Bansal et al., 2009), a protein that is abundant in cells from nervous system and in neoplastic cells of neural tumors (Katsetos et al., 2003). TBB3 is involved in axon guidance, thus mutations in this protein are associated with different nervous system disorders (Tischfield et al., 2010). In living cells and in vitro models, polyclonal antibodies with high affinity for beta tubulin have been shown to disrupt cytoplasmic microtubules, leading to their fragmentation into smaller units (Füchtbauer et al., 1985).

In addition to the self-reactive proteins mentioned above, the dendritic tree of Purkinje cell is another host component that has been considered a target of autoimmune responses in CM. In a cohort of Thai individuals, it has been demonstrated that levels of autoantibodies against dendrites are higher in P. falciparuminfected patients with CM than in those with uncomplicated malaria (Gallien et al., 2011). The pathogenic role of such autoantibodies was attributed to their ability in inhibiting in vitro development of Purkinje cells (Calvet et al., 1993). However, it is important to emphasize that these results were obtained from studies conducted with cat brain biopsies and thus, should be interpreted with caution.

On the other hand, a possible role in protection against severe $P$. falciparum malaria has already been suggested for selfreactive antibodies induced during plasmodial infection. This is the case of $\operatorname{IgE}$ autoantibodies to $14-3-3 \varepsilon$ brain protein, which induce in vitro mastocyte degranulation (Duarte et al., 2012). The 14-3-3 $\varepsilon$ brain protein belongs to a family of adaptor proteins that interact with a multitude of binding partners that contain PSer/PThr motifs. Through this interaction, 14-3-3 $\varepsilon$ protein affects the activity and localization of various substrate proteins, regulating signal cascades of a wide range of biological activities, including cell cycle and apoptosis (Cornell and ToyoOka, 2017). Therefore, 14-3-3 $\varepsilon$ protein has been implicated in different neurodegenerative and neuropsychiatric diseases by mechanisms that vary from apoptosis to protein stabilization and aggregation (For further details see Foote and Zhou, 2012 and Cornell and Toyo-Oka, 2017). In Parkinson's disease, for example, the interaction of 14-3-3 $\varepsilon$ protein with Bad and Bax proteins prevents neurons apoptosis. Neurodegeneration is avoided by interaction between 14-3-3 $\varepsilon$ protein and phosphorylated tyrosine hydroxylase in parallel with the binding between $\alpha$-synuclein to unphosphorylated tyrosine hydroxylase. An imbalance in those interactions leads to neurodegeneration in this nervous system disorder (Shimada et al., 2013). Thus, it is not surprising that an antibody response against 14-3-3 $\varepsilon$ brain protein exert neuroprotective properties, as it has already been demonstrated in glaucoma, using a neuro-retinal cell line of mouse origin. In this case, cell viability and reduced reactive oxygen species levels were considered predictors of protection (Bell et al., 2015).

As highlighted herein, the repertoire of brain antigens that are targets of autoimmune responses during CM is vast and depends on a complex interplay of host, parasite and environmental factors. However, whether such autoantibodies have a pathogenic relevance, can be considered biomarkers of neuropathology or are merely innocent by-standers remains a focus of debate. More studies are needed in order to elucidate this, as well as to determine the epitopes, function and origin of such selfreactive immunoglobulins. Even though it is known that a breach in the blood brain barrier's (BBB) integrity is necessary to allow antibody influx into the brain (Huerta et al., 2006), studies conducted with post mortem brain tissues from Malawian children with fatal cerebral malaria revealed that, although BBB breakdown occurs in vessels containing cytoadherent parasitized RBCs, no gross leakage of plasma proteins occurs (Brown et al., 2001). Thus, the mechanisms by which immunoglobulins gain access to brain tissue are another issue that is still to be elucidated. Do they cross the BBB independently or do plasma cells secrete them? Further studies are necessary to understand in more details how BBB breakdown occurs in malaria. Understanding how this happens may provide new opportunities to find agents that are able to open the BBB, allowing the delivery of different molecules and shedding light on the effects of antibodies in the brain tissue. This knowledge may pave the way for the development of future interventions for malaria and other neurological diseases.

\section{RENAL DYSFUNCTION}

Acute renal failure is most reported in $P$. falciparum infections (Frutakul et al., 1974; Burchard et al., 2003; von Seidlein et al., 2012; Conroy et al., 2016; Sypniewska et al., 2017; Rivera-Correa et al., 2019b), but this complication can occasionally occurs in infection due to P. malariae (Neri et al., 2008; Badiane et al., 2016). Renal failure is considered a clinical manifestation with high prognostic value to severe malaria (von Seidlein et al., 2012; Sypniewska et al., 2017). In P. malariae infection, renal failure affects most children and is presented as steroidresistant nephrotic syndrome. The pathogenesis is possibly mediated through immune-complex deposition containing IgM, IgG, C3, and malarial antigens in mesangiocapillary, glomerular, proximal tubules and subendothelial kidney tissues, with rarely IgA deposition (Ward and Kibuka-Musoke, 1969; Houba et al., 1971; van Velthuysen and Florquin, 2000; Das, 2008). Chronic glomerular disease due to $P$. malariae infection is usually not reversible even after treatment, raising the hypothesis that genetic and environmental factors are also involved (Houba, 1979). Although it is well-known that P. malariae-associated 
renal impairment is caused mainly because of immune complex deposits, there are no studies investigating if autoantibodies are involved in this process.

In P. falciparum malaria, acute renal failure is a common and serious complication in non-immune adults and adolescents and is more frequent in patients from non-endemic regions (Barsoum, 2000; Elsheikha and Sheashaa, 2007; Nguansangiam et al., 2007), but it can also occur in pediatric severe malaria (Olowu and Adelusola, 2004; von Seidlein et al., 2012; Conroy et al., 2016; Sypniewska et al., 2017; Rivera-Correa et al., 2019b). Although it is an important clinical manifestation associated with mortality and morbidity, the pathogenesis of renal failure in $P$. falciparum malaria is not well understood. However, unlikely $P$. malariae-associated renal failure, acute kidney injury in $P$. falciparum infection is usually transient and disappears after treatment (van Velthuysen and Florquin, 2000), suggesting that the parasite does not have a great role in the pathogenesis that is most likely to be caused by host's immune response. Several hypothesis on the pathogenesis of malarial renal failure have been proposed, including mechanical obstruction of glomerular and tubulointerstitial capillaries by infected erythrocytes (Seydel et al., 2006; Nguansangiam et al., 2007), possibly leading to renal ischemia (Conroy et al., 2016); immune complex deposits leading to renal impairment (Frutakul et al., 1974); and autoantibodies against nucleic acids (Wozencraft et al., 1990; Rivera-Correa et al., 2019b).

In a children population from Uganda, Rivera-Correa et al. (2019b) demonstrated that infants with severe P. falciparum malaria manifesting acute kidney injury have autoantibodies against nucleic acid and lipids. Additionally, they found a correlation between those autoantibodies and creatinine and blood urea nitrogen levels, two indicators of kidney health, suggesting that such immunoglobulins may play a role in kidney injury. It was also shown that anti-DNA autoantibodies were elevated in children with acute kidney injury, a result that is in accordance with Wozencraft et al. (1990), who obtained similar data, however, in mouse malaria. It is important to mention that no difference was found in levels of antibodies against parasite antigen, indicating that systemic changes in IgG metabolism and immune-mediated pathways may contribute to malaria-associated renal failure. This result corroborates the findings from Frutakul et al. (1974), who reported an absence of antibodies against parasite antigens in immune complexes deposited in glomeruli capillary walls from a Thai child's kidney. All these data demonstrate that renal dysfunction due to autoantibodies may be relevant in severe $P$. falciparum-associated renal failure. Future investigations should be conducted to further understand the role of those autoantibodies, their involvement in renal pathogenesis, as well as their use as disease biomarkers.

\section{ANEMIA}

Anemia is the most common feature and a major concern in malaria, mainly in young children and pregnant women (Accrombessi et al., 2015; Kenangalem et al., 2016; White, 2018).
Despite its relevance, the pathogenesis of malaria-associated anemia is complex, and still incompletely understood. Malariainduced anemia is thought to arise from the rupture of infected and non-infected red blood cells (nRBCs), as well as inappropriate erythropoiesis in the erythroid germinal centers (Douglas et al., 2012; White, 2018). But the greater loss is due to the clearance of nRBCs, which persist long after infection has resolved (Looareesuwan et al., 1987; Ritter et al., 1993; Collins et al., 2003; Douglas et al., 2012). An autoimmune component has been suggested to explain this removal, although the mechanisms underlying autoimmunity in malarial anemia have not been thoroughly explored (White, 2018; Rivera-Correa and Rodriguez, 2019). Self-reactive antibodies that recognize RBCs have been documented in plasmodial infections since 1970s, when hostserum components associated with the surface of nRBCs were detected in patients with malaria using different methodologies (Rosenberg et al., 1973; Facer et al., 1979; Berzins et al., 1983; Fernandez-Arias et al., 2016; Mourão et al., 2016). However, their roles in the pathophysiology of anemia have not been thoroughly explored. Evidence in this line is given by studies that have shown a reduction in $\mathrm{RBC}$ life span following the clearance of $P$. falciparum (Looareesuwan et al., 1987). This reduction in RBC survival time has been observed mainly in anemic patients and is associated with the deposition of complement containing immune complexes on RBCs surface (Rosenberg et al., 1973). Furthermore, it has been demonstrated that autoantibodies against triosephosphate isomerase purified from patients with $P$. falciparum malaria can bind to RBCs, promoting their lysis and activating complement cascade thereby, contributing to anemia (Ritter et al., 1993).

Since these early findings, autoantibodies with other specificities have already been identified and associated to anemia in malaria. This is the case of anti-phosphatidylserine (PS) antibodies, which were found to tag nRBCs exposing phosphatidylserine (Fernandez-Arias et al., 2016; Barber et al., 2019; Rivera-Correa et al., 2019a). These self-reactive immunoglobulins have been shown to increase in vitro phagocytosis and in vivo clearance of nRBCs, contributing to malarial anemia in a murine model (Fernandez-Arias et al., 2016). Moreover, a negative correlation between the magnitude of anti-PS antibodies and hemoglobin levels has been reported for patients infected with $P$. falciparum and P. vivax (Barber et al., 2019; Rivera-Correa et al., 2019a,b). In addition, it has been demonstrated that a population of atypical B cells, which is characterized by the expression of CD11c and T-bet, secretes anti-PS antibodies. The activation of these cells has been shown to be dependent of parasite DNA and different receptors have been suggested to be involved such as interferon- $\gamma$ receptor (IFN- $\gamma \mathrm{R}$ ), B-cell receptor (BCR) and Toll-like receptor 9 (TLR9) (Rivera-Correa et al., 2017). However, the role of such atypical cells in human malaria was still unknown until a recent evidence has emerged from a study conducted with $P$. falciparum-infected returned travelers (Rivera-Correa et al., 2019a). In this study, it has been shown that FcRL5 ${ }^{+} \mathrm{T}_{\text {-bet }}{ }^{+} \mathrm{B}$-cells are expanded in acute malaria. Additionally, it has been observed that naïve human peripheral blood mononuclear cells are able to produce anti-PS antibodies when stimulated with lysates of $P$. falciparum-infected 
TABLE 1 | Autoantibodies against self-antigens and their implications in P. falciparum and P. vivax malaria.

\begin{tabular}{|c|c|c|c|}
\hline Self antigen & $\begin{array}{l}\text { Possible functional activity of } \\
\text { self-reactive antibody }\end{array}$ & Clinical outcome & References \\
\hline $14-3-3 \varepsilon$ brain protein & $\begin{array}{l}\text { Degranulation of mast cells, basophils, } \\
\text { eosinophils and/or monocytes/macrophages }\end{array}$ & $\begin{array}{l}\text { Protection against severe Plasmodium } \\
\text { falciparum malaria }\end{array}$ & Duarte et al., 2012 \\
\hline Beta tubulin III (TBB3) & Cytoplasm microtubule disruption & $\begin{array}{l}\text { Cerebral malaria associated to } P \text {. } \\
\text { falciparum }\end{array}$ & $\begin{array}{l}\text { Füchtbauer et al., 1985; Bansal } \\
\text { et al., } 2009\end{array}$ \\
\hline Dendritic tree of Purkinje cell & In vitro inhibition of Purkinje cells development & $\begin{array}{l}\text { Cerebral malaria associated to } P \text {. } \\
\text { falciparum }\end{array}$ & $\begin{array}{l}\text { Calvet et al., 1993; Gallien et al., } \\
2011\end{array}$ \\
\hline \multirow[t]{2}{*}{ Erythrocyte band 3 protein } & $\begin{array}{l}\text { Rigidity increase and in vitro clearance of } \\
\text { non-parasitized RBCs }\end{array}$ & Anemia associated to Plasmodium vivax & Mourão et al., 2016, 2018 \\
\hline & $\begin{array}{l}\text { In vitro P. falciparum cythoadherence blockage } \\
\text { and in vivo adherence of RBCs; parasite } \\
\text { growth inhibition }\end{array}$ & Protection against $P$. falciparum malaria & $\begin{array}{l}\text { Hogh et al., } 1994 \text {; Brahimi et al., } \\
2011\end{array}$ \\
\hline Lipids & $\begin{array}{l}\text { Kidney injury through immune complex } \\
\text { deposition }\end{array}$ & $\begin{array}{l}\text { Renal failure associated to } P \text {. falciparum } \\
\text { malaria }\end{array}$ & $\begin{array}{l}\text { Frutakul et al., 1974; } \\
\text { Rivera-Correa et al., 2019b }\end{array}$ \\
\hline Non-erythroid alpha spectrin & $\begin{array}{l}\text { Disruption of brain cells cytoskeleton; } \\
\text { complement activation and amplification of } \\
\text { neuronal damage }\end{array}$ & $\begin{array}{l}\text { Cerebral malaria associated to } P \text {. } \\
\text { falciparum }\end{array}$ & Guiyedi et al., 2007 \\
\hline Nucleic acids & $\begin{array}{l}\text { Kidney injury through immune complex } \\
\text { deposition }\end{array}$ & $\begin{array}{l}\text { Renal failure associated to } P \text {. falciparum } \\
\text { malaria }\end{array}$ & $\begin{array}{l}\text { Frutakul et al., 1974; } \\
\text { Rivera-Correa et al., 2019b }\end{array}$ \\
\hline Phosphatidylserine & $\begin{array}{l}\text { Phagocytosis (in vitro) and clearance of } \\
\text { non-parasitized RBCs }\end{array}$ & $\begin{array}{l}\text { Anemia associated to } P \text {. falciparum and } P \text {. } \\
\text { vivax }\end{array}$ & $\begin{array}{l}\text { Fernandez-Arias et al., 2016; } \\
\text { Barber et al., 2019; Rivera-Correa } \\
\text { et al., 2019a }\end{array}$ \\
\hline Spectrin & $\begin{array}{l}\text { Disruption of RBCs cytoskeleton; amplification } \\
\text { of RBCs damage }\end{array}$ & Anemia associated to $P$. vivax & Mourão et al., 2018 \\
\hline Triose-phosphate isomerase & $\begin{array}{l}\text { In vitro lysis of } \mathrm{RBC} \text { and activation of } \\
\text { complement }\end{array}$ & Anemia associated to $P$. falciparum & Ritter et al., 1993 \\
\hline Voltage-gated calcium channels (VGCC) & $\begin{array}{l}\text { Complement-independent downregulation of } \\
\text { calcium flow in Purkinge and granule cells }\end{array}$ & $\begin{array}{l}\text { Cerebral malaria associated to } P \text {. } \\
\text { falciparum }\end{array}$ & Lang et al., 2005 \\
\hline
\end{tabular}

RBCs, highlighting such atypical subset of memory B cells as a major promoter of autoimmune anemia in malaria. Besides antiPS antibodies, self-reactive immunoglobulins triggered by other host cell targets are also involved in RBCs lysis, as it has been evidenced in a complement lysis assay using annexin $\mathrm{V}$ to block the binding of anti-PS antibodies to phosphatidylserine. After the binding of annexin to PS, RBC lysis could be partially inhibited by plasma from $P$. falciparum-infected patients (Rivera-Correa et al., 2019a).

Autoantibodies against RBCs have also been described for P. vivax infections (Mourão et al., 2016, 2018; Ventura et al., 2018; Barber et al., 2019). However, since this parasite has unique biological features that restricts its invasion to reticulocytes, lower densities of peripheral parasitemia are generally expected for infections due to $P$. vivax in comparison to $P$. falciparum. But despite this, $P$. vivax causes a greater loss of nRBCs. Thus, it is possible that the mechanisms leading to nRBCs removal in $P$. vivax malaria are distinct from those observed from $P$. falciparum. More work is needed to elucidate this.

Different erythrocytic antigens have been shown to be recognized by self-reactive immunoglobullins from anemic $P$. vivax-infected patients such as band 3 (Mourão et al., 2018), an anion exchanger protein which mediates the change of intracellular bicarbonate $\left(\mathrm{HCO}_{3}^{-}\right)$to extracellular chloride $\left(\mathrm{Cl}^{-}\right)$ (Cordat and Reithmeier, 2014). Since IgGs purified from the same patients can bind to the surface of non-parasitized RBCs, increasing their rigidity and enhancing their clearance by THP-1 phagocytes (Mourão et al., 2018), it is also possible that anti-RBCs antibodies mediate malarial anemia through erythrophagocytosis or through decreasing RBC deformability (Mourão et al., 2016). Other possibility is the withdrawn from circulation by mechanisms like those tagging senescent RBCs for clearance (Lutz and Bogdanova, 2013), a hypothesis that should be better investigated.

Other RBC protein that has also been considered a target for autoimmune responses during $P$. vivax malaria is spectrin, although it is still unclear how anti-spectrin antibodies bind to an inner component of RBC membrane. Since in silico analysis revealed that human spectrin primary structure shares homology with a $P$. vivax hypothetical protein, it is possible that molecular mimicry drives autoimmune response against human spectrin (Mourão et al., 2018), a hypothesis that needs to be experimentally validated.

On the other hand, no association between anti-RBCs antibodies and anemia has been observed in a study conducted with $P$. vivax-infected children and adolescents from Pará, a State located in Brazilian Amazon (Ventura et al., 2018). A similar result was also found by (Fernandes et al., 2008), who evaluated the frequency of malarial anemia, as well as cytokines and autoantibodies levels, in an area in which $P$. vivax and $P$. falciparum coexists. It is important to mention that despite no significant association has been found in both studies, 
BOX 1 | Outstanding questions in autoimmunity-mediated pathology in malaria:

- Which mechanisms are behind the generation of self-reactive antibodies in malaria?

- What are the self-antigens that trigger auto-immune responses in $P$. falciparum and $P$. vivax malaria?

- How self-reactive antibodies penetrate the blood-brain barrier, a high selective barrier that protects the central nervous system from invaders? Do they cross independently or do plasma cells secrete them?

- Do self-reactive antibody responses change with anti-malarial therapy?

- Is there any association between autoantibodies that persist after parasite clearance and long-term complications?

- What is the prevalence and the magnitude of autoantibody responses in different epidemiological settings?

- Can anti-self-antibody blockage prevent pathology?

higher frequency of anti-RBCs antibodies has been reported in patients with malaria (Fernandes et al., 2008; Ventura et al., 2018).

In other reports, a beneficial role has been attributed to antiRBCs antibodies. This is the case of a study carried out in an area of intense transmission of malaria in Liberia, where it has been shown that immune responses to band 3 neoantigens are correlated with lower P. falciparum parasitemia and can block in vitro and in vivo RBCs' cytoadherence (Hogh et al., 1994). Moreover, an anti-plasmodial activity has been proposed to autoantibodies from patients with autoimmune diseases, which were able to inhibit parasite growth, suggesting a protective role for those molecules, although the authors have not ruled out the involvement of other serum components (Brahimi et al., 2011). Since the pathways involved in autoantibody-induced pathology differ among infections due to different parasites, it is possible that self-reactive antibodies exert diverse effects in infections by $P$. vivax and $P$. falciparum, an issue that should be target of future investigation.

As can be noted by the findings mentioned above, the literature concerning self-reactive antibodies against RBCs suggest a dual role for these immunoglobulins in malariaassociated anemia. But crucial gaps remain to be addressed (Box 1).

These scientific breakthroughs will allow the use of autoantibodies as signatures to predict disease severity

\section{REFERENCES}

Accrombessi, M., Ouédraogo, S., Agbota, G. C., Gonzalez, R., Massougbodji, A., Menéndez, C., et al. (2015). Malaria in pregnancy is a predictor of infant haemoglobin concentrations during the first year of life in Benin, West Africa. PLoS ONE 10:e0129510. doi: 10.1371/journal.pone.012 9510

Adebajo, A. O., Charles, P., Maini, R. N., and Hazleman, B. L. (1993). Autoantibodies in malaria, tuberculosis and hepatitis B in a west African population. Clin. Exp. Immunol. 92, 73-76. doi: 10.1111/j.1365-2249.1993.tb05950.x or protection, as well as provide insights toward the best vaccination strategies. Furthermore, they will open new therapeutic possibilities to treat malarial anemia.

\section{CONCLUDING REMARKS}

Studies regarding autoantibodies and plasmodial infections have indicated that those molecules may play a dual role in malaria (Figure 1 and Table 1). However, it is not clear if self-reactive antibodies lead to pathogenesis or are just a consequence of plasmodial infection. Although different self-reactive antibodies have been identified in distinct populations and associated with clinical complications, their epitopes as well as their origin and functional role remains to be elucidated. This information will be essential to the search and identification of epitopes and other molecules that can hijacks pathogenic autoantibodies from circulation, minimizing or inhibiting their pathogenic effects in host cells. This is an interesting field of work that should be focus of future investigation using in vitro and in vivo models. Since few reports have associated autoantibodies to protection, this is an issue that should also be better investigated. Additionally, it would be of interest to determine the prevalence and the magnitude of self-reactive responses in cohorts from different epidemiological settings, an analysis that should be extended including prospective studies. The role of self-immunoglobulins isotypes and IgG subclasses is another gap that should also be addressed. A better knowledge of all these points (Box 1) may allow the use of autoantibodies as signatures to predict malaria clinical outcome. Furthermore, it may open new therapeutic possibilities to treat malariaassociated complications besides have implications for other autoimmune diseases.

\section{AUTHOR CONTRIBUTIONS}

LM, GC-O, and EB conceptualized and wrote the manuscript.

\section{FUNDING}

Funding for preparation of this review: CNPq (404365/20167 and 154378/2018-6), CAPES (88887.472593/2019-00), FAPEMIG (APQ-00361-16).
Adu, D., Williams, D. G., Quakyi, I. A., Voller, A., Anim-Addo, Y., Bruce-Tagoe, A. A., et al. (1982). Anti-ssDNA and antinuclear antibodies in human malaria. Clin. Exp. Immunol. 49, 310-316

Antonelli, L. R., Junqueira, C., Vinetz, J. M., Golenbock, D. T., Ferreira, M. U., and Gazzinelli, R. T. (2019). The immunology of Plasmodium vivax malaria. Immunol. Rev. 293, 163-189. doi: 10.1111/imr.12816

Badiane, A. S., Diongue, K., Diallo, S., Ndongo, A. A., Diedhiou, C. K., Deme, A. B., et al. (2016). Acute kidney injury associated with Plasmodium malariae infection. Malar. J. 13:226. doi: 10.1186/1475-2875-13-226

Bansal, D., Herbert, F., Lim, P., Deshpande, P., Bécavin, C., Guiyedi, V., et al. (2009). IgG autoantibody to brain beta tubulin III associated with cytokine 
cluster-II driscriminate cerebral malaria in central India. PLoS ONE 4:e8245. doi: 10.1371/journal.pone.0008245

Barber, B. E., Grigg, M. J., Piera, K., Amante, F. H., William, T., Boyle, M. J., et al. (2019). Antiphosphatidylserine immunoglobulin $M$ and immunoglobulin $\mathrm{G}$ antibodies are higher in vivax than falciparum malaria, and associated with early anemia in both species. J. Infect. Dis. 220, 1435-1443. doi: 10.1093/infdis/jiz334

Barsoum, R. S. (2000). Malarial acute renal failure. J. Am. Soc. Nephrol. 11, 2147-2154. doi: 10.46-6673/1111-2147

Bell, K., Wilding, C., Funke, S., Pfeiffer, N., and Grus, F. H. (2015). Protective effect of 14-3-3 antibodies on stressed neuroretinal cells via the mitochondrial apoptosis pathway. BMC Ophthalmol. 15:64. doi: 10.1186/s12886-015-0044-9

Berzins, K., Wahlgren, M., and Perlmann, P. (1983). Studies on the specificity on anti-erythrocyte antibodies in the serum of patients with malaria. Clin. Exp. Immunol. 54, 313-318.

Birbeck, G. L., Molyneux, M. E., Kaplan, P. W., Seydel, K. B., Chimalizeni, Y. F., Kawaza, K., et al. (2010). Blantyre malaria project epilepsy study (BMPES) of neurological outcomes in retinopathy-positive paediatric cerebral malaria survivors: a prospective cohort study. Lancet 9, 1173-1181. doi: 10.1016/S1474-4422(10)70270-2

Brahimi, K., Martins, Y. C., Zanini, G. M., Ferreira-da-Cruz, M. F., and DanielRibeiro, C. T. (2011). Monoclonal auto-antibodies and sera of autoimmune patients react with Plasmodium falciparum and inhibit its in vitro growth. Mem. Inst. Oswaldo Cruz 106, 44-51. doi: 10.1590/s0074-02762011000900006

Brown, H., Rogerson, S., Taylor, T., Tembo, M., Mwenechanya, J., Molyneux, M., et al. (2001). Blood-brain barrier function in cerebral malaria in Malawian children. Am. J. Trop. Med. Hyg. 64, 207-213. doi: 10.4269/ajtmh.2001.64.207

Burchard, G. D., Ehrhardt, S., Mockenhaupt, F. P., Mathieu, A., Agana-Nsiire, P., Anemana, S. D., et al. (2003). Renal dysfunction in children with uncomplicated Plasmodium falciparum malaria in Tamale, Ghana. Ann. Trop. Med. Parasit. 97, 345-350. doi: 10.1179/000349803235002281

Calvet, M. C., Druilhe, P., Camacho-Garcia, R., and Calvet, J. (1993). Culture model for the study of cerebral malaria: antibodies from Plasmodium falciparum-infected comatose patients inhibit the dendritic development of Purkinje cells. J. Neurosci. Res. 36, 235-240. doi: 10.1002/jnr.490360214

Collins, W. E., Jeffery, G. M., and Roberts, J. M. (2003). A retrospective examination of anemia during infection of humans with Plasmodium vivax. Am. J. Trop. Med. 68, 410-412.

Conroy, A. L., Hawkes, M., Elphinstone, R. E., Morgan, C., Hermann, L., Barker, K. R., et al. (2016). Acute kidney injury is common in pediatric severe malaria and is associated with increased mortality. Open Forum Infect. Dis. 3:ofw046. doi: 10.1093/ofid/ofw046

Cordat, E., and Reithmeier, R. A. (2014). Structure, function, and trafficking of SLC4 and SLC26 anion transporters. Curr. Top. Membr. 73, 1-67. doi: 10.1016/B978-0-12-800223-0.00001-3

Cornell, B., and Toyo-Oka, K. (2017). 14-3-3 proteins in brain development: neurogenesis, neuronal migration and neuromorphogenesis. Front. Mol. Neurosci. 10:318. doi: 10.3389/fnmol.2017.00318

Couper, K. N., Barnes, T., Hafalla, J. C. R., Combes, V., Ryffel, B., Secher, T., et al. (2010). Parasite-derived plasma microparticles contribute significantly to malaria infection-induced inflammation through potent macrophage stimulation. PLoS Pathog. 6:e1000744. doi: 10.1371/journal.ppat. 1000744

Damian, R. T. (1964). Molecular mimicry: antigen sharing by parasite and host and its consequences. Am. Nat. 98, 129-149.

Daniel-Ribeiro, C., Druilhe, P., Monjour, L., Homberg, J. C., and Gentilini, M. (1983). Specificity of auto-antibodies in malaria and the role of polyclonal activation. Trans. R. Soc. Trop. Med. Hyg. 77, 185-188. doi: 10.1016/0035-9203(83)90064-0

Das, B. S. (2008). Renal failure in malaria. J. Vector Borne Dis. 45, 83-97.

Donati, D., Zhang, L. P., Chêne, A., Chen, Q., Flick, K., Nyström, M., et al. (2004). Identification of a polyclonal B-cell activator in Plasmodium falciparum. Infect. Immun. 72, 5412-5418. doi: 10.1128/IAI.72.9.5412-5418.2004

Douglas, N. M., Anstey, N. M., Buffet, P. A., Poespoprodjo, J. R., Yeo, T. W., White, N. J., et al. (2012). The anaemia of Plasmodium vivax malaria. Malar. J. 11:135. doi: 10.1186/1475-2875-11-135

Duarte, J., Herbert, F., Guiyedi, V., Franetich, J. F., Roland, J., Cazenave, P. A., et al. (2012). High levels of immunoglobulin E autoantibody to 14-3-3 epsilon protein correlate with protection against severe Plasmodium falciparum malaria. J. Infect. Dis. 206, 1781-1789. doi: 10.1093/infdis/jis595

Elsheikha, H. M., and Sheashaa, H. A. (2007). Epidemiology, pathophysiology, management and outcome of renal dysfunction associated with plasmodia infection. Parasitol. Res. 101, 1183-1190. doi: 10.1007/s00436-007-0 650-4

Facer, C. A., and Agiostratidou, G. (1994). High levels of antiphospholipid antibodies in uncomplicated and severe Plasmodium falciparum and P. vivax malaria. Clin. Exp. Immunol. 95, 304-309. doi: 10.1111/j.1365-2249.1994.tb06528.x

Facer, C. A., Bray, R. S., and Brown, J. (1979). Direct Coombs antiglobulin reactions in Gambian children with Plasmodium falciparum malaria. I. incidence and class specificity. Clin. Exp. Immunol. 35, 119-127.

Fernandes, A. A., Carvalho, L. J., Zanini, G. M., Ventura, A. M., Souza, J. M., Cotias, P. M., et al. (2008). Similar cytokine responses and degress of anemia in patients with Plasmodium falciparum and Plasmodium vivax infections in the Brazilian Amazon region. Clin. Vaccine Immunol. 15, 650-658. doi: 10.1128/CVI.00475-07

Fernandez-Arias, C., Rivera-Correa, J., Gallego-Delgado, J., Rudlaff, R., Fernandez, C., Roussel, C., et al. (2016). Anti-self-phosphatidylserine antibodies recognize uninfected erythrocytes promoting malarial anemia. Cell Host Microbe. 19, 194-203: doi: 10.1016/j.chom.2016.01.009

Flanagan, K. L., Plebanski, M., Odhiambo, K., Sheu, E., Mwangi, T., Gelder, C., et al. (2006). Cellular reactivity to the P. falciparum protein TRAP in adult kenyans: novel epitopes, complex cytokine patterns, and yhe impact of natural antigenic variation. Am. J. Trop. Med. Hyg. 74, 367-375.

Fontaine, A., Pophillat, M., Bourdon, S., Villard, C., Belghazi, M., Fourget, P., et al. (2010). Specific antibody responses against membrane proteins of erythrocytes infected by Plasmodium falciparum of individuals briefly exposed to malaria. Malar. J. 9:276. doi: 10.1186/1475-2875-9-276

Foote, M., and Zhou, Y. (2012). 14-3-3 proteins in neurological disorders. Int. J. Biochem. Mol. Biol. 3, 152-164.

Freeman, R. R., and Parish, C. R. (1978). Polyclonal B-cell activation during rodent malarial infections. Clin. Exp. Immunol. 32, 41-45

Frutakul, P., Boonpucknavig, V., Boonpucknavig, S., Mitrakul, C., and Bhamarapravati, N. (1974). Acute glomerulonephritis complicating Plasmodium falciparum infection. Clin. Pediatr. 13, 281-283. doi: $10.1177 / 000992287401300315$

Füchtbauer, A., Herrmann, M., Mandelkowl, E., and Jockusch, M. (1985). Disruption of microtubules in living cells and cell models by high affinity antibodies to beta-tubulin. EMBO. 4, 2807-2814.

Fujinami, R. S., von Herrath, M. G., Christen, U., and Whitton, J. L. (2006). Molecular mimicry, bystander activation, por viral persistence: infections and autoimmune disease. Clin. Microbiol. Rev. 19, 80-94. doi: 10.1128/CMR.19.1.80-94.2006

Gallien, S., Roussilhon, C., Blanc, C., Pérignon, J. L., and Druilhe, P. (2011). Autoantibody against dendrite in Plasmodium falciparum infection: a singular auto-immune phenomenon preferentially in cerebral malaria. Acta Trop. 118, 67-70. doi: 10.1016/j.actatropica.2011.01.005

Gitau, E. N., Kokwaro, G. O., Karanja, H., Newton, C. R., and Ward, S. A. (2013). Plasma and cerebrospinal proteomes from children with cerebral malaria differ from those of children with other encephalopathies. J. Infect. Dis. 208, 1494-1503. doi: 10.1093/infdis/jit334

Greenwood, B. M. (1974). Possible role of a B-cell mitogen in hypergammaglobulinaemia in malaria and trypanosomiasis. Lancet 1 , 435-436. doi: 10.1016/s0140-6736(74)92386-1

Guiyedi, V., Chanseaud, Y., Fesel, C., Snounou, G., Rousselle, J. C., Lim, P., et al. (2007). Self-reactivities to the non-erythroid alpha spectrin correlate with cerebral malaria in Gabonese children. PLOS ONE 2:e389. doi: 10.1371/journal.pone.0000389

Haneji, N. T., Nakamura, K., Takio, K., Yanagi, H., and Higashiyama, I. (1997). Identification of alpha-fodrin as a candidate autoantigen in primary Sjogren's syndrome. Science, 276, 604-607. doi: 10.1126/Science.276.5312.604

Hogh, B., Petersen, E., Crandall, I., Gottschau, A., and Sherman, I. W. (1994). Immune responses to band 3 neoantigens on Plasmodium falciparum-infected erythrocytes in subjects living in an area of intense malaria transmission are associated with low parasite density and high hematocrit value. Infect. Immunol. 62, 4362-4366. 
Holmgren, A. M., McConkey, C. A., and Shin, S. (2017). Outrunning the red queen: bystander activation as a means of outpacing innate immune subversion by intracellular pathogens. Cell. Mol. Immmunol. 14, 14-21.

Houba, V. (1979). Immunologic aspects of renal lesions associated with malaria. Kidney Int. 16, 3-8. doi: 10.1038/ki.1979.96

Houba, V., Allison, A. C., Adeniyi, A., and Houba, J. E. (1971). Immunoglobulin classes and complement biopsies of Nigerian children with the nephrotic syndrome. Clin. Exp. Immunol. 8, 761-774.

Huerta, P. T., Kowal, C., DeGiorgio, L. A., Volpe, B. T., Diamond, B. (2006). Immunity and behavior: antibodies alter emotion. Proc. Natl. Acad. Sci. U.S.A. 103, 678-683. doi: 10.1073/pnas. 0510055103

Idro, R., Marsh, K., John, C. C., Newton, C. R. (2010). Cerebral malaria: mechanisms of brain injury and strategies for improved neurocognitive outcome. Pediatr. Res. 68, 267-274. doi: 10.1203/00006450-201011001-00524

Irani, S., and Lang, B. (2008). Autoantibody-mediated disorders of the central nervous system. Autoimmunity 41, 55-65. doi: 10.1080/08916930701619490

Jakobsen, P. H., Morris-Jones, S. D., Hviid, L., Theander, T. G., Høier-Madsen, M., Bayoumi, R. A., et al. (1993). Anti-phospholipid antibodies in patients with Plasmodium falciparum malaria. Immunology 79, 653-657.

Katsetos, G. D., Herman, M. M., and Mörk, S. J. (2003). Class III $\beta$-tubullin in human development and cancer. Cell Motil. Cytoskeleton 55, 77-96. doi: $10.1002 / \mathrm{cm} .10116$

Kenangalem, E., Karyana, M., Burdarm, L., Yeung, S., Simpson, J. A., Tjitra, E., et al. (2016). Plasmodium vivax infection: a major determinant of severe anaema in infancy. Malar. J. 15:321. doi: 10.1186/s12936-016-1373-8

Lacerda, M. V., Mourão, M. P., Coelho, H. C., and Santos, J. B. (2011). Thrombocytopenia in malaria: who cares? Mem. Inst. Oswaldo Cruz. 106(Suppl. 1), 52-63. doi: 10.1590/s0074-02762011000900007

Lang, B., Newbold, C. I., Williams, G., Peshu, N., Marsh, K., and Newton, C. R. (2005). Antibodies to voltage-gated calcium channels in children with falciparum malaria. J. Infect. Dis. 191, 117-121. doi: 10.1086/426512

Looareesuwan, S., Merry, A. H., Phillips, R. E., Pleehachinda, R., Wattanagoon, Y., Ho, M., et al. (1987). Reduced erythrocyte survival following clearance of malarial parasitaemia in Thai patients. Br. J. Haematol. 67, 473-478. doi: 10.1111/j.1365-2141.1987.tb06171.x

Ludin, P., Nilsson, D., and Maser, P. (2011). Genome-wide identification of molecular mimicry candidates in parasites. PLoS One 6:e17546. doi: 10.1371/journal.pone.0017546

Ludwig, R. J., Vanhoorelbeke, K., Leypoldt, F., Kaya, Z., Bieber, K., McLachlan, S. M., et al. (2017). Mechanisms of autoantibody-induced pathology. Front. Immunol. 8:603. doi: 10.3389/fimmu.2017.00603

Lutz, H. U., and Bogdanova, A. (2013). Mechanisms tagging senescent red blood cells for clearance in healthy humans. Front. Physiol. 4:387. doi: 10.3389/fphys.2013.00387

MaCDonald, S. M., Bhisutthiban, J., Shapiro, T. A., Rogerson, S. J., Taylor, T. E., Tembo, M., et al. (2001). Immune mimicry in malaria: Plasmodium falciparum secretes a functional histamine-releasing factor honmolog in vitro and in vivo. Proc. Natl. Acad. Sci. U.S.A. 98, 10829-10832. doi: 10.1073/pnas.20 1191498

Mantel, P., Hoang, A.n., Goldowitz, I., Potashnikova, D., Hamza, B., Vorobjev, I., et al. (2013). Malaria-infected erythrocyte-derived microvesicles mediate cellular communication within the parasite population and with the host immune system. Cell Host Microbe. 13, 521-534. doi: 10.1016/j.chom.2013.04.009

Minoprio, P. (2001). Parasite polyclonal activators: new targets for vaccination approaches? Int. J. Parasitol. 31, 583-591. doi: 10.1016/S0020-7519(01)00171-0

Molyneux, M. E., Taylor, T. E., Wirima, J. J., and Borgstein, A. (1989). Clinical features and prognostic indicators in paediatric cerebral malaria: a study of 131 comatose Malawian children. Q. J. Med. 71, 441-459.

Mourão, L. C., Baptista, R. P., Almeida, Z. B., Grynberg, P., Pucci, M. M., CastroGomes, T., et al. (2018). Anti-band 3 and anti-spectrin antibodies are increased in Plasmodium vivax infection and are associated with anemia. Sci. Rep. 6:8762. doi: 10.1038/s41598-018-27109-6

Mourão, L. C., Roma, P. M., Sultane-Aboobacar, J. S., Medeiros, C. M., de Almeida, Z. B., Fontes, C. J., et al. (2016). Anti-erythrocyte antibodies may contribute to anaemia in Plasmodium vivax malaria by decreasing red blood cell deformability and increasing erythrophagocytosis. Malar. J. 15:397. doi: $10.1186 / \mathrm{s} 12936-016-1449-5$
Moxon, C. A., Gibbins, M. P., McGuinness, D., Milner, D. A., and Marti, M. (2019). New insights into malaria pathogenesis. Annu. Rev. Pathol. 15. doi: 10.1146/annurev-pathmechdis-012419-032640

Münz, C., Lünemann, J. D., Getts, M. T., and Miller, S. D. (2009). Antiviral immune responses: triggers of or triggered by autoimmunity? Nat. Rev. Immunol. 9, 246-258. doi: $10.1038 /$ nri2527

Nath, R., Raser, K. J., Stafford, D. (1996). Non-erythroid alpha-spectrin breakdown by calpain and interleukin I beta-converting-enzyme-like protease(s) in apoptotic cells: contributory roles of both protease families in neuronal apoptosis. Biochem. J. 319, 683-690. doi: 10.1042/bj3190683

Neri, S., Pulvirenti, D., Patamia, I., Zoccolo, A., and Castellino, P. (2008). Acute renal failure in Plasmodium malariae infection. Neth. J. Med. 66, 166-168.

Nguansangiam, S., Day, N. P. J., Hien, T. T., Mai, N. T. H., Chaisri, U., Riganti, M., et al. (2007). A quantitative ultrastructural study of renal pathology in fatal Plasmodium falciparum malaria. Trop. Med. Int. Health. 12, 1037-1050. doi: 10.1111/j.1365-3156.2007.01881.x

Olowu, W. A., and Adelusola, K. A. (2004). Pediatric acute renal failure in southwestern Nigeria. Kidney Int. 66, 1541-1548. doi: 10.1111/j.1523-1755.2004.00918.x

Pinto, A., Gillard, S., Moss, F., Whyte, K., Brust, P., Williams, M., et al. (1998). Human autoantibodies specific for the alphal A calcium channel subunit reduce both P-type and Q-type calcium currents in cerebellar neurons. Proc. Natl. Acad. Sci. U.S.A. 95, 8328-8333. doi: 10.1073/PNAS.95.14.8328

Ritter, K., Kuhlencord, A., Thomssen, R., and Bommer, W. (1993). Prolonged haemolytic anaemia in malaria and autoantibodies against triosephosphate isomerase. Lancet 342, 1333-1334. doi: 10.1016/0140-6736(93)92248-r

Rivera-Correa, J., Conroy, A. L., Opoka, R. O., Batte, A., Namazzi, R., Ouma, B., et al. (2019b). Autoantibody levels are associated with acute kidney injury, anemia and post-discharge morbidity and mortality in Ugandan children with severe malaria. Sci. Rep. 9:14840. doi: 10.1038/s41598-019-51426-z

Rivera-Correa, J., Guthmiller, J. J., Vijay, R., Fernandez-Arias, C., Pardo-Ruge, M. A., Gonzalez, S., et al. (2017). Plasmodium DNA-mediated TLR9 activation of T-bet ${ }^{+}$B cells contributes to autoimmune anaemia during malaria. Nat. Commun. 8:1282. doi: 10.1038/s41467-017-01476-6

Rivera-Correa, J., Mackroth, M. S., Jacobs, T., Schulze Zur Wiesch, J., Rolling, T., and Rodriguez, A. (2019a). Atypical memory B-cells are associated with Plasmodium falciparum anemia through anti-phosphatidylserine antibodies. Elife 8:e48309. doi: 10.7554/eLife.48309

Rivera-Correa, J., and Rodriguez, A. (2019). Autoimmune anemia in malaria. Trends Parasitol. 36, 91-97. doi: 10.1016/j.pt.2019.12.002

Rosenberg, E. B., Strickland, G. T., Yang, S. L., and Whalen, G. E. (1973). IgM antibodies to red cells and autoimmune anemia in patients with malaria. Am. J. Trop. Med. Hyg. 22, 146-152. doi: 10.4269/ajtmh.1973.22.146

Rosenberg, Y. J. (1978). Autoimmune and polyclonal B cell responses during murine malaria. Nature 264, 170-172. doi: 10.1038/274 $170 \mathrm{a} 0$

Seydel, K. B., Milner, D. A., Kamiza, S. B., Molyneux, M. E., and Taylor, T. E. (2006). The distribution and intensity of parasite sequestration in comatose Malawian children. J. Infect. Dis. 194, 208-205. doi: 10.1086/50 5078

Shimada, T., Fournier, A. E., and Yamagat, K. (2013). Neuroprotective function of 14-3-3 proteins in neurodegeneration. Biomed. Res. Int. 2013:564534. doi: $10.1155 / 2013 / 564534$

Sypniewska, P., Duda, J. F., Locatelli, I., Althaus, C. R., Althaus, F., Genton, B. (2017). Clinical and laboratory predictors of death in African children with features of severe malaria: a systematic review and meta-analysis. BMC Med. 15:147. doi: 10.1186/s12916-017-0906-5

Taylor, T. E., Fu, W. J., Carr, R. A., Whitten, R. O., Mueller, J. S., Fosiko, N. G., et al. (2004). Differentiating the pathologies of cerebral malaria by postmortem parasite counts. Nat. Med. 10, 143-145. doi: 10.1038/nm986

Teasdale, G., and Jennett, B. (1974). Assessment of coma and impaired consciousness. a practical scale. Lancet 2, 81-84. doi: 10.1016/s0140-6736(74)91639-0

Teo, A., Feng, G., Brown, G. V., Beeson, J. G., and Rogerson, S. J. (2016). Functional antibodies and protection against blood-stage malaria. Trends Parasitol. 32, 867-898. doi: 10.1016/j.pt.2016.07.003

Tischfield, M. A., Baris, H. N., Wu, C., Rudolph, G., Van Maldergem, L., He, W., et al. (2010). Human TUBB3 mutations perturb microtubule dynamics, kinesin 
interactions, and axon guidance. Cell 140, 74-87. doi: 10.1016/j.cell.2009. 12.011

van Velthuysen, M. L. F., and Florquin, S. (2000). Glomerulopathy associated with parasitic infections. Clin. Microbiol. Rev. 13, 55-66. doi: $10.1128 / \mathrm{cmr} .13 .1 .55-66.2000$

Vanderlugt, C. L., and Miller, S. D. (2002). Epitope spreading in immune-mediated diseases: implications fior immunotherapy. Nat. Rev. Immunol. 2, 85-95. doi: $10.1038 /$ nri724

Ventura, A. M. R. S., Fernandes, A. A. M., Zanini, G. M., Pratt-Riccio, L. R., Sequeira, C. G., do Monte, C. R. S., et al. (2018). Clinical and immunological profiles of anaemia in children and adolescentes with Plasmodium vivax malaria in the Pará state. Brazilian Amazon. Acta Trop. 181, 122-131. doi: 10.1016/j.actatropica.2018.01.022

von Seidlein, L., Olaosebikan, R., Hendriksen, I. C. E., Lee, S. J., Adedoyin, O. T., Agbenyega, T., et al. (2012). Predicting the clinical outcome of severe falciparum malaria in African children: findings from a large randomized trial. Clin. Infect. Dis. 54, 1080-1090. doi: 10.1093/cid/cis034

Ward, P. A., and Kibuka-Musoke, J. W. (1969). Evidence for soluble immune complexes in the pathogenesis of the glomerulonephritis of quartan malaria. Lancet 1, 283-285.
White, N. J. (2018). Anaemia and malaria. Malar. J. 17:371. doi: 10.1186/s12936-018-2509-9

WHO | World Malaria Report (2019). WHO. Available online at: https://www. who.int/publications-detail/world-malaria-report-2019 (accessed on January 02, 2020).

Wozencraft, A. O., Lloyd, C. M., Staines, N. A., and Griffiths, V. J. (1990). Role of DNA-binding antibodies in kidney pathology associated with murine malaria infections. Infect Immun. 58, 2156-2164.

Conflict of Interest: The authors declare that the research was conducted in the absence of any commercial or financial relationships that could be construed as a potential conflict of interest.

Copyright (c) 2020 Mourão, Cardoso-Oliveira and Braga. This is an open-access article distributed under the terms of the Creative Commons Attribution License (CC $B Y)$. The use, distribution or reproduction in other forums is permitted, provided the original author(s) and the copyright owner(s) are credited and that the original publication in this journal is cited, in accordance with accepted academic practice. No use, distribution or reproduction is permitted which does not comply with these terms. 